\title{
Training of Physical Education Teachers in the Context of Digital Education Implementation
}

\section{Formación de profesores de educación física en el contexto de la aplicación de la educación digital}

\author{
Nikolay Petrovich Olesov* \\ Ammosov North-Eastern Federal University, Yakutsk, Russia \\ ORCID: https://orcid.org/0000-0002-8396-9559 \\ Nikolay Efimovich Gogolev \\ Ammosov North-Eastern Federal University, Yakutsk, Russia \\ ORCID: https://orcid.org/0000-0002-7964-8939 \\ Vladimir Polikarpovich Barakhsanov \\ Ammosov North-Eastern Federal University, Yakutsk, Russia \\ ORCID: https://orcid.org/0000-0001-7648-6922 \\ Arian Egorovich Tarasov \\ Ammosov North-Eastern Federal University, Yakutsk, Russia \\ ORCID: https://orcid.org/0000-0002-0702-2494 \\ Vladimir Gavrilievich Torgovkin \\ Ammosov North-Eastern Federal University, Yakutsk, Russia \\ ORCID: https://orcid.org/0000-0001-5296-8193
}

Recibido 02-11-19 Revisado 15-12-19 Aprobado 13-03-20 En línea 16-03-20

Correspondencia

Email: nikolay.olesov@yandex.ru
Citar como:
Olesov, N.P., Gogolev, N.E., Barakhsanov, V.P., Tarasov, A.E., Torgovkin, V.G. (2020). Training of Physical Education Teachers in the Context of Digital Education Implementation. Propósitos y Representaciones, 8(3). doi: http://dx.doi.org/10.20511/pvr2020.v8n3.482

(C) Universidad San Ignacio de Loyola, Vicerrectorado de Investigación, 2020. 


\section{Summary}

In the context of digital education implementation, addressing the problem pertaining to the training of highly qualified physical education (PE) teachers in the Republic of Sakha (Yakutia) is essential for the innovative development of the region, along with that of its scientific and educational environments. To this end, specialists should improve their professional skills in order to develop and effectively use advanced educational technologies that take into account the specific conditions of work, study, life as well as the national and cultural traditions of the region. The current article highlights that the implementation of digital education requires complex transformations in the systems of both pedagogical and physical education, which are influenced by progressive digital and information technologies. However, its practical implementation requires a change in the goals, along with the organizational forms and technologies of educational activities, based on information and communication technology (ICT) and network technologies, in addition to the development of productive strategies to integrate innovations into the traditional educational process. Thus, the aim of this study is to substantiate the current trends regarding the development of digital education and training of PE teachers in the Republic of Sakha (Yakutia), by means of the analyses of foreign and domestic researchers' experiences. Further, its theoretical aspect delves into the analysis of the research conducted on digital education and, primarily, the ways in which it can be implemented in the educational process of the Institute of Sport and Physical Education (ISPE), Ammosov NorthEastern Federal University (NEFU). On the other hand, the practical section of this study presents a comparison between the knowledge of part-time and full-time students studying at the ISPE, NEFU, concerning the framework of digital educational materials' implementation for the training of future PE teachers. The results showed the considerable improvement of the students' knowledge on the importance of ICT and digital resources, in addition to an increased level of digital competence regarding professional activity.

Keywords: Digital Education, E-Learning, Physical Education, Informational Training of Teachers.

\section{Resumen}

En el contexto de la aplicación de la educación digital, abordar el problema relativo a la formación de profesores de educación física altamente cualificados en la República de Saja (Yakutia) es esencial para el desarrollo innovador de la región, junto con el de sus entornos científicos y educativos. Con ese fin, los especialistas deben mejorar sus aptitudes profesionales para desarrollar y utilizar eficazmente tecnologías educativas avanzadas que tengan en cuenta las condiciones específicas de trabajo, estudio y vida, así como las tradiciones nacionales y culturales de la región. En el presente artículo se destaca que la aplicación de la educación digital requiere transformaciones complejas en los sistemas de educación tanto pedagógica como física, que se ven influidas por las tecnologías digitales e informáticas progresivas. Sin embargo, su aplicación práctica requiere un cambio en los objetivos, así como en las formas de organización y las tecnologías de las actividades educativas, basadas en la tecnología de la información y las comunicaciones (TIC) y las tecnologías de redes, además del desarrollo de estrategias productivas para integrar las innovaciones en el proceso educativo tradicional. Así pues, el objetivo de este estudio es fundamentar las tendencias actuales en cuanto al desarrollo de la educación y la formación digital de los profesores de educación física en la República de Saja (Yakutia), mediante el análisis de las experiencias de los investigadores extranjeros y nacionales. Además, su aspecto teórico profundiza en el análisis de las investigaciones realizadas sobre la educación digital y, principalmente, en las formas en que puede aplicarse en el proceso educativo del Instituto de Deportes y Educación Física (ISPE) de la Universidad Federal del Nordeste de Ammosov (NEFU). Por otra parte, en la sección práctica de este estudio 
se presenta una comparación entre los conocimientos de los estudiantes a tiempo parcial y a tiempo completo que estudian en el ISPE, NEFU, en lo que respecta al marco de aplicación de los materiales educativos digitales para la formación de los futuros profesores de educación física. Los resultados mostraron una mejora considerable de los conocimientos de los estudiantes sobre la importancia de las TIC y los recursos digitales, además de un mayor nivel de competencia digital en relación con la actividad profesional.

Palabras Clave: Educación Digital; E-Learning; Educación Física; Formación informativa de Profesores.

\section{Introduction}

Digital education development in the Republic of Sakha (Yakutia) led to the analysis of socioeconomic conditions of indigenous peoples of the North as part of the implementation of digital economy. Nowadays, the regional educational system has entered a phase of significant transformation caused by global digitalization (Zeibote, Volkova \& Todorov, 2019). In order to be effective, physical education needs to change rapidly, and in order to be a leader it is necessary to change at a faster pace. Previous educational models and their methods of implementation are becoming less effective. Former methods of communication often do not work between participants of the educational process. The types of student activities, models of obtaining knowledge and operating with them, often change. It is necessary to design a development strategy for ISPE in the context of a dynamic digital modernization of education as a whole. The training for future teachers of physical education and sports is the basis for this innovation. Thus, this sector of education in the Republic of Sakha (Yakutia) is directly influenced by the effectiveness of digitalization.

Over the years, in the context of the strategic program in NEFU, "Effective University Implementation," IFCS conducts research work on the implementation of digital technologies in the educational and training process. Interactive forms of training are based on the analysis of the implementation of e-learning in advanced training courses, workshops, round tables and group discussions, with the participation of employers. The purpose of the events is, as follows:

1) To identify trends in the modification of physical education and in the context of elearning implementation;

2) To develop new models and technologies for training future PE teachers, including various types of didactic informative and educational resources and technologies focused on the trends of digital education modification.

To achieve the highest degree of application and effectiveness of digital education (DE) for the system of physical education, it is necessary to provide training for teachers in this field, taking into account the following factors:

- Implementation of new knowledge on the use of digital technologies and resources in the educational process of the Institute of Physical Education. It should meet the main interests and motives of the teacher in order to get maximum involvement and confidence in this area;

- Adaptation of PE teacher to new realities that arise through the provision of concepts and procedures;

- Correlation between theory and practice at all stages of training. 
The authors analyzed the necessity to implement electronic teaching means and network technologies in educational and training activities in the initial training for PE teachers in accordance with Federal State Educational Standard (FSES HE 3++). This can improve the quality of education. The main tools for training teachers of PE and coaches are information technology and software. This will also allow them to combine study with personal and professional responsibilities. In addition, teachers can be involved in the management process in the sphere of physical education.

\section{Literature review}

The issue of digital education is relevant in the training of teachers of PE and sports in the region. The author analyzed regulatory documents for the implementation of digital education based on e-learning in schools and universities in Russia. The analysis showed that it is carried out in accordance with the requirements of FSEA HE 3++. The researchers point out the particular importance of the informatization of education in context of the implementation of digital education based on e-learning in educational process of the university.

Foreign researchers are focused on the development of the students' digital competence and the use of digital education in higher education institutions. In particular, Clark \& Mayer (2016), Chen et al. (2018), Gunter \& Reeves (2017), Yang et al. (2017) and Schulz, Isabwe \& Reichert (2014) analyzed the students and teachers' satisfaction with e-learning systems offered by higher education institutions. The authors highlighted national and regional specifics and characteristics of pedagogical needs in innovative electronic information and educational environment.

Belisle \& Rosado (2006) declare that literacy does not only provide methods and tools for operating with texts and numbers in a specific cultural and ideological context. It also improves human thinking. This intellectual enrichment occurs whenever humanity gains new cognitive tools, such as writing, or technical tools provided by digital technology.

Bravo, Pons \& Pagán (2018) pointed out that information and communication technologies (ICT) play a significant role in the process of educational system management development. Teacher continuous training, personal and professional responsibilities are also important.

According to Fernandez Batanero \& Rodriguez-Martin (2017), student must accumulate knowledge based on the experience. This will allow him to serve as a link to the new knowledge that he will receive in the educational process. Therefore, the training will be constructive and effective.

Gutierrez \& Torrego (2018) point out that the professional training of teachers, particularly in the field of media education, requires a clarification of concepts.

The study rests on the Russian researchers' theories in the field of adaptive and e-learning education, artificial intelligence, and information technology, published from 2014 to 2019 in foreign journals, the Scopus, and Web of Science databases (Vlasova et al., 2018; Vlasova, Avksentieva, Goncharova \& Aksyutin, 2019).

Materials on informatization and distance learning in the field of physical education, published in the journal Theory and Methods of Physical Culture and Sports, provide the idea that the content and specificity of digital education for teacher training, including teachers of PEand sports, is not studied enough in the regional educational system of the Republic of Sakha (Yakutia) (Barakhsanov, Barakhsanova, Olesov \& Prokopyev, 2018). The authors contend that 
a theoretical understanding of the implementation of digital education in universities of the Republic of Sakha (Yakutia) would solve problems in the determination of the students' digital dependence in their educational activity and practice.

The team led by Gogolev introduced the work "Organizational Peculiarities of Scientific Activities of Future Specialists in the Sphere of Physical Education and Sports" (Gogolev, Glukhareva, Sabaraikin \& Ivanov, 2015). Here, the authors pointed out that the educational and training process in the ISPE of NEFU is organized in accordance with modern scientific achievements and the systematic updating of all aspects of education. Particular attention is paid to the synthesis of theoretical and practical training in this area, which should contribute to the development of independent scientific works (Gogolev, Glukhareva, Sabaraikin \& Ivanov, 2015). In their article titled "On the Informational Support of the Process of Training Specialists in Physical Education," Sergin \& Khompodoeva (2012) reveal the main directions of informational support of physical culture and sports. Furthermore, the work of Sergin \& Lytkina (2012) focuses on the interactive forms of support of the pedagogical internship of students of physical education universities.

It is worth highlighting that implementation of the modern information technologies in the training of PE teachers provides the opportunity to develop the social knowledge necessary for cooperative and individual study. In addition, we can test the importance of a new culture, digital technology and the development of a new society in the context of the PE teachers' training.

\section{Method}

Nowadays, in the context of the development of the university digital environment, such informational systems as electronic platforms are introduced (Alasmri, Onn \& Hin, 2019). The platform provides the opportunity to create one's products via offsite developers by means of built-in open tools, which are connected to other products on a single platform. The electronic platform is regarded as a learning management system (LMS) and a means of automated development for distance and electronic courses (Vlasova et al., 2018). The most famous LMS is the modular object-oriented dynamic learning environment Moodle. It has a wide range of offerings. For instance, there are more than 100,000 sites and more than 16,000 courses registered on the Moodle LMS. In addition, training on work and practice programs has been introduced in electronic library systems and electronic educational resources.

In the context of digital education implementation, PE cannot work according to the former model and with the previous efficiency using traditional processes, methods, educational technologies, and tools. Modern students and teachers are the drivers of change, and their preferences can determine the form of working with students, ways by which knowledge is obtained, and how interaction with the educational environment is carried out.

The authors of the present study analyze strategic transformations in ISPE of NEFU. As a result, they identify several important factors and directions of digital education implementation in the training of teachers for the Republic of Sakha (Yakutia). This study reveals the technological trends and directions of development of ICT competencies among the students of ISPE. In total, the study involves over 300 full- and part-time students.

In addition to electronic surveys, the results of individual and group interviews were used in the experiment. Bachelor's and master's level students took part in the survey.

The researchers analyzed the dynamics of the process of future teacher training in the framework of the digitalization of education, considering the specific regional characteristics of 
the northern context. It was revealed that it is necessary to design a strategy of digital modernization of pedagogical education in accordance with the digital innovation trends, including digital resources, tools, and services. It was confirmed that the implementation of new types of educational activities provides the innovative professional training of a modern teacher in a digital society. At the same time, it is necessary to review the content and technological support of the professional training of modern teachers and scientific-pedagogical workers to develop relevant and in-demand digital competencies, such as the following:

- The ability to work with cloud and web technologies in the context of educational problem solving;

- The rational use of digital platforms;

- The ability to engage in multivariate online communication, including interprofessional interaction;

- The development of electronic and mobile training;

- The integrated use of artificial intelligence methods and digital technologies to perform multitasking, integrated and creative work.

Electronic educational resources include electronic and distance learning courses, which comprise sets of teaching materials and educational programs implemented in the informational education environment according to the normative documents for the discipline.

In their practice, the authors apply training material on technological support based on the implementation of electronic resources. The purpose is improving the knowledge about digital education and developing a public consciousness, which allows the subject to act correctly in relation to particular informational issues. Moreover, improving the knowledge about the informational and educational environment allows the subject to apply technologies as educational supports. Each year (from 2016 to 2019), two groups of part-time and full-time first year students of the specialization physical education at NEFU were asked the following question: "Do you think that network technology and electronic resources are necessary for training teachers of PE and sports in Yakutia?" At the significance level $\alpha=0.02(\alpha=0.88)$, the authors tested the hypothesis that part-time teachers and full-time students of ISPE consider the implementation of digital education activity for teachers of physical culture and sports is necessary for their professional success.

The necessity of the digitalization of physical education in the Republic of Sakha (Yakutia) is confirmed by particular results obtained after the experimental data processing. More than 120 part-time students and more than 200 full-time students took part in the survey. The data were processed by means of the hypothesis test algorithm about equality of the attribute ratio. For the significance level $\alpha=0.02$, the values of $t_{\mathrm{cr}}=2.33$ were looked up in the tables. As, $|t|<t_{\kappa p}$, the hypothesis is that both part-time and full-time students of ISFE consider digital transformation to be equally demanded for their future professional activities. Within the framework of the study, students were asked to analyze the degree of significance of the studied digital technologies for the transformation of their digital competencies

Table 1 shows the rankings of digital technologies. The rankings were applied to find Spearman's rank correlation coefficient, $r_{\mathrm{s}}=0.909$. There is a positive correlation between the opinions of the students of the two groups on the issue at a significance level of $\alpha=0.05$, as 
$t_{\text {est }}>t_{\text {cr }}(6.89>2.23)$. The correlation between the opinion of full-time and part-time study groups is statistically significant at a 5\% significance level.

\section{Table 1.}

Rank Indicators of Digital Technologies That Influence the Digital Transformation of the Students' Informational Competencies

\begin{tabular}{ccc}
\hline Digital Technologies & $\begin{array}{c}\text { Rank in a Full-Time } \\
\text { Students Sample }\end{array}$ & $\begin{array}{c}\text { Rank in a Part-Time } \\
\text { Students Sample }\end{array}$ \\
\hline Cloud technologies & 1 & 1 \\
\hline Distance Learning Technologies & 4 & 3 \\
\hline Virtual educational environments & 12 & 10 \\
\hline Mobile Learning Technologies & 4 & 2 \\
\hline Internet tools & 10 & 8 \\
\hline Web Portfolio & 9 & 7 \\
\hline Infographics & 9 & 5 \\
\hline Podcasts, Video Casts & 5 & 10 \\
\hline Augmented Reality & 12 & 7 \\
\hline QR-codes & 9 & 8 \\
\hline Chats, forums & 7 & 3 \\
\hline Webinars & 2 &
\end{tabular}

It is necessary to design a strategy for digital modernization of pedagogical education in accordance with the trends of digital innovations, including digital resources, tools, and services. In addition, the following skills and abilities should be developed:

- the operation of cloud and web technologies for solving educational problems;

- the application of reasonable digital platforms; interaction;

- the usage of multivariate online communications, including interprofessional

- the implementation of electronic and mobile training; and

- the combination of artificial intelligence and digital technology methods to perform multitasking, as well as integrated and creative educational work.

A set of test tasks was performed as a control and a means of measuring material for assessing the digital competencies that influenced the study. 
Table 2.

The Level of Digital Competency of Future PE Teachers

\begin{tabular}{|c|c|}
\hline Competency Components & Quantity (\%) \\
\hline $\begin{array}{l}\text { 1. Search, input, conversion, output of necessary (heterogeneous) } \\
\text { information using informational and communicational technologies }\end{array}$ & 70.5 \\
\hline $\begin{array}{l}\text { 2. Introduction of information: texts, images, formulas, video content in } \\
\text { various forms, operating with data via telecommunication channels. }\end{array}$ & 64 \\
\hline $\begin{array}{l}\text { 3. Modeling tools use. Conducting various training sessions in a virtual } \\
\text { environment. }\end{array}$ & 40.4 \\
\hline $\begin{array}{l}\text { 4. Self-expression on the Internet (unique content creation) using modern } \\
\text { ICT tools. }\end{array}$ & 80 \\
\hline $\begin{array}{l}\text { 5. Knowledge of the methodology for educational ICTs design (development } \\
\text { and methodology of using content to model situations occurring in } \\
\text { professional activities). }\end{array}$ & 78 \\
\hline $\begin{array}{l}\text { 6. Understanding of the restrictions and possibilities of informational and } \\
\text { communicational technologies implementation in the field of PE and sports }\end{array}$ & 82 \\
\hline $\begin{array}{l}\text { 7. The ability to evaluate developed competencies by means of various } \\
\text { methods of assessment (tests, projects, etc.). }\end{array}$ & 42.3 \\
\hline 8. The ability to conduct classes on the subject using ICT technologies. & 52.3 \\
\hline $\begin{array}{l}\text { 9. Understanding the psychological and pedagogical problems of teacher- } \\
\text { student-computer interaction in the framework of educational process. }\end{array}$ & 70 \\
\hline $\begin{array}{l}\text { 10. The use of informational and communicational technologies to receive, } \\
\text { transmit and process various information. }\end{array}$ & 68.9 \\
\hline
\end{tabular}

\section{Results}

The knowledge level of future PE teachers will vary in maturity and different formation. Thus, the authors interpret the results of the experiment, evaluating the levels of digital competence, in the following categories: cognitive, methodological, and special.

Table 3 shows the result of the formation of the compulsory minimum and advanced levels of digital competence for the selected components (cognitive, methodological, and special). 
Table 3.

Students' Levels of Digital Competencies at the Beginning and at the End of the Experimental Work $(E W)$

\begin{tabular}{|c|c|c|c|c|c|c|c|c|c|c|c|c|c|c|c|c|c|}
\hline \multirow{5}{*}{\multicolumn{2}{|c|}{$\begin{array}{l}\text { Competency } \\
\text { Content }\end{array}$}} & \multicolumn{16}{|c|}{ Competency Levels } \\
\hline & & \multicolumn{8}{|c|}{ Full-Time Students } & \multicolumn{8}{|c|}{ Part-Time Students } \\
\hline & & \multicolumn{4}{|c|}{ Compulsory } & \multicolumn{4}{|c|}{ Advanced } & \multicolumn{4}{|c|}{ Compulsory } & \multicolumn{4}{|c|}{ Advanced } \\
\hline & & \multicolumn{2}{|c|}{$\mathrm{CG}$} & \multicolumn{2}{|c|}{ EG } & \multicolumn{2}{|c|}{$\mathrm{CG}$} & \multicolumn{2}{|c|}{ EG } & \multicolumn{2}{|c|}{$\mathrm{CG}$} & \multicolumn{2}{|c|}{ EG } & \multicolumn{2}{|c|}{$\mathrm{CG}$} & \multicolumn{2}{|c|}{ EG } \\
\hline & & $\mathrm{S}$ & $\mathrm{E}$ & $\mathrm{S}$ & $E$ & $\mathrm{~S}$ & $\mathrm{E}$ & S & $\mathrm{E}$ & $\mathrm{S}$ & $\mathrm{E}$ & $S$ & $E$ & $\mathrm{~S}$ & $\mathrm{E}$ & $\mathrm{S}$ & $\mathrm{E}$ \\
\hline \multirow{4}{*}{ Cognitive } & hours & 1 & 6 & 1 & 3 & 2 & 1 & 2 & 1 & 1 & 6 & 1 & 4 & 3 & 9 & 4 & 1 \\
\hline & & 5 & & 6 & & & 1 & & 5 & 2 & & 2 & & & & & 2 \\
\hline & $\%$ & 8 & 3 & 8 & 1 & 1 & 6 & 1 & 8 & 8 & 4 & 7 & 2 & 2 & 6 & 2 & 7 \\
\hline & & 8 & 5 & 9 & 7 & 2 & 5 & 1 & 3 & 0 & 0 & 5 & 5 & 0 & 0 & 5 & 5 \\
\hline \multirow[t]{4}{*}{ Methodical } & hours & 1 & 5 & 1 & 5 & 3 & 1 & 2 & 1 & 1 & 4 & 1 & 3 & 3 & 1 & 2 & 1 \\
\hline & & 4 & & 6 & & & 2 & & 4 & 2 & & 4 & & & 1 & & 3 \\
\hline & $\%$ & 8 & 2 & 8 & 2 & 1 & 7 & 1 & 7 & 8 & 2 & 8 & 1 & 2 & 7 & 1 & 8 \\
\hline & & 2 & 9 & 9 & 1 & 8 & 1 & 1 & 8 & 0 & 7 & 8 & 9 & 0 & 3 & 3 & 1 \\
\hline \multirow[t]{4}{*}{ Special } & hours & 1 & 7 & 1 & 4 & 2 & 1 & 1 & 1 & 1 & 4 & 1 & 4 & 0 & 1 & 1 & 1 \\
\hline & & 5 & & 7 & & & 0 & & 5 & 5 & & 5 & & & 1 & & 2 \\
\hline & $\%$ & 8 & 4 & 9 & 1 & 1 & 6 & 6 & 8 & 9 & 2 & 9 & 2 & 0 & 7 & 6 & 7 \\
\hline & & 8 & 1 & 3 & 7 & 2 & 0 & & 3 & 6 & 7 & 2 & 5 & & 3 & & 5 \\
\hline
\end{tabular}

Note: CG - a control group, EG - an experimental group, $\mathrm{S}$ - start, E - end

In order to understand whether the future PE teachers able to use digital technologies and electronic resources, they were offered to design an educational project related to their specialty. As a result, the students of the experimental group coped with the task (42.4\%), and only $15.5 \%$ of the students in the control group managed to do the task. Also, 5.9\% of the experimental respondents and $30 \%$ of the control group respondents did not complete the task. Students of the experimental group regarded the educational process as a means of improvement of their professional qualities, as well as mastering the necessary knowledge and skills.

According to the students of the experimental group, the effective organization of the teaching methodology for the discipline "Information Technologies in Education" provides the ability to consider the goal, identify tasks (planning, forecasting and activity of the results), to analyze the decisions and the quality of the educational process.

Most of the participants from the experimental group (65.5\%) note that the motivation for them was the training project itself with a "quality educational result". The authors introduced a table for the level of the component of demand and motivation for information and communication technologies implementation.

Table 4.

The Values of Student's t-Criterion

\begin{tabular}{cccc}
\hline \multirow{2}{*}{ Group } & \multicolumn{4}{c}{ Criterion } \\
\cline { 2 - 4 } & $\begin{array}{c}\text { Demand and } \\
\text { Motivation }\end{array}$ & $\begin{array}{c}\text { Operational and } \\
\text { Effectual }\end{array}$ & $\begin{array}{c}\text { Evaluative and } \\
\text { Reflective }\end{array}$ \\
\hline CG & 2.8 & 5.6 & 7.9 \\
\hline EG & 29.8 & 0.5 & 9.5 \\
\hline
\end{tabular}


In the context of the analysis of the level of ICT competencies, there observed the following qualitative changes in the experimental group of the future PE teachers:

- the vast majority of future teachers set themselves up for positive self-realization;

- designed educational project with a great interest;

- placed confidence in the professor and group mates;

- showed patience and ability for pedagogical communication in unusual situations;

- strove to determine the target strategies of the modular object-oriented dynamic learning environment Moodle;

-members of the experimental group showed personal responsibility for the implementation of electronic means and ICT in educational activity.

\section{Discussion}

Pedagogical experience of NEFU shows that such informational educational environment has been created here that provides great opportunities for the development of students' digital competence. In this aspect, the ISPE of NEFU is carrying out educational methodical, research, health care and sports work. The results of a survey, conducted among full-time and part-time students of the physical education major in NEFU, showed their awareness of the importance of digital education. At the same time, the survey revealed the necessity to improve theoretical basis of this work and to make corrections in it to form a more holistic understanding of the significant components of digital education, the necessity of the network technologies and electronic resources implementation in educational and training activities.

The purpose of the study was to prove the necessity of the basic training so that future teachers of PE and sports can adequately use electronic resources in their educational practice.

\section{Conclusion}

The study showed that steady development of education in the northern regions requires timely initiatives of the educational innovators who have mastered digital technologies and understood their importance for the digital competencies development. Quick training and retraining of teachers is required for the development of new digital education system in the northern regions.

The research problem is caused by the implementation of one of the priority tasks for the modernization of regional education in Russia. It includes the necessity to implement digital education, reflecting the partnership of Russian universities in the training of teaching staff and the implementation of the Government Decree on the implementation of the Digital Economy in education.

In the context of digital education implementation, physical education cannot be effective if supporting old model, using traditional processes, methods, educational technologies and tools. The authors introduced the analysis of the strategic transformations in the ISPE of NEFU.

The researches made a conclusion, that the theoretical understanding of the implementation of digital education in universities of the Republic of Sakha (Yakutia) allowed us to reveal the significance of digital education for the training of teachers in the region. 


\section{References}

Alasmri, M., Onn, W.C., \& Hin, H.S. (2019). Social Networking Framework for Learning Motivation. Journal of Southwest Jiaotong University, 54(6). Recuperado de http://jsju.org/index.php/journal/article/view/450

Barakhsanov, V.P., Barakhsanova, E.A., Olesov, N.P., \& Prokopyev, M.S. (2018). E-learning system application for physical education and sports specialist training. Theory and Practice of Physical Culture, 7, 4.

Belisle, C., \& Rosado, E.A. (2006). Analysing Digital Literacy Frameworks. European Framework for Digital Literacy. Recuperado de http://halshs.archives-ouvertes.fr/docs

Bravo, M.P.C., Pons, J.P., \& Pagán, J.B. (2018). The Impact of ICT in the Spanish Education System: A Survey Summery. RED. Distance Learning Journal, 56, 2. Recueperado de http://www.um.es/ead/red/56/colas_et_al.pdf

Chen, Q., Lo, C.K.M., Zhu, Y., Cheung, A., Chan, K.L., \& Ip, P. (2018). Family polyvictimization and cyberbullying among adolescents in a Chinese school sample. Child Abuse and Neglect, 77, 180-187.

Clark, R.C., \& Mayer, R.E. (2016). E-Learning and the Science of Instruction: Proven Guidelines for Consumers and Designers of Multimedia Learning. John Wiley \& Sons.

Fernandez Batanero, J.M., \& Rodriguez-Martin, A. (2017). ICT and functional diversity: knowledge of the teaching staff. European Journal of Investigation in Health, Psychology and Education, 7(3), 157-175.

Gogolev, N.E., Glukhareva, M.R., Sabaraikin, S.V., \& Ivanov, Yu.V. (2015). Organizational peculiarities of scientific activities of future specialists in the sphere of physical education and sports. Theory and Practice of Physical Education, 10, 9-10.

Gunter, G.A. \& Reeves, J.L. (2017). Online professional development embedded with mobile learning: An examination of teachers' attitudes, engagement and dispositions. British Journal of Educational Technology, 48, 1305-1317.

Gutierrez, M.A., \& Torrego, G.A. (2018). Media education and teacher training. Interuniversity Pedagogical Magazine, 91(32.1). Recuperado de https://aufop.com/aufop/uploaded_files/revistas/15332190632.pdf

Schulz, R., Isabwe, G.M., \& Reichert, F. (2014). Supporting teachers' needs within and through E-learning systems. IEEE 2014 International Conference on Web and Open Access to Learning. doi: http://dx.doi.org/10.1109/ICWOAL.2014.7009228

Sergin, A.A., \& Khompodoeva, M.V. (2012). On the informational support of the process of training specialists in physical education. Pedagogical Informatics, 5, 18-22.

Sergin, A.A., \& Lytkina, S.T. (2012). Interactive forms of supporting the teaching internship of the students of physical education universities. 5.

Vlasova, E.Z., Avksentieva, E.Y., Goncharova, S.V., \& Aksyutin, P.A. (2019). Artificial intelligence - The space for the new possibilities to train teachers. Espacios, 40(9), 17.

Vlasova, E.Z., Barakhsanova, E.A., Goncharova, S., Aksyutin, P., Kuzin, Z., \& Prokopyev, M.S. (2018). Effective adaptive training of students in Russian pedagogical universities to use e-learning technologies. Education, 39(23), 10.

Yang, C.Y., Chung, T.Y., Hwang, M.S., Li, C.Y., \& Yao, J.F.J. (2017). Learning Performance Evaluation in eLearning with the Web-Based Assessment. In: Kim, K., Joukov, N. (Eds.), Information Science and Applications 2017. ICISA 2017. Lecture Notes in Electrical Engineering (pp. 645-651), vol. 424. Singapore: Springer.

Zeibote, Z., Volkova, T., \& Todorov, K. (2019). The impact of globalization on regional development and competitiveness: cases of selected regions. Insights into Regional Development, 1(1), 33-47. 